Nummer: $\quad 10$ Datum: 1987-02-11

Titel:

Stabilization of marginal aggregates with hydraulic and puzzolanic binders based on waste materials

Författare: Peet Höbeda

Avdelning: $\quad V$

Projektnummer: $4200601-5$

Projektnamn: Restprodukter

Uppdragsgivare: VTI

Distribution: fri / r 


\title{
STABILIZATION OF MARGINAL AGGREGATES WITH HYDRAULIC AND PUZZOLANIC BINDERS BASED ON WASTE MATERIALS
}

\author{
STABILISATION DE GRANULATS MARGINAUX AVEC DES LIANTS A BASE DE DECHETS
}

\author{
HÖBEDA Peet *
}

\begin{abstract}
Natural sand deposits and waste screenings from gravel pits and quarries are abundant in parts of Sweden. Investigations have been made to stabilize such materials with binders based on waste materials. Both laboratory work and test roads have been performed. In the latter case, mainly secondary roads have been strengthened with a plant-mixed bases.

Good results have been achieved with a binder made of milled granulated blast furnace slag, activated with lime or especially with both lime and waste gypsum. Sand and screenings from gravel often contain organic material, deleterous with the binders studied. In such cases, the gypsum addition also seems to counteract the negative effect of the organic material. Fly ash has recently been available in Sweden. Tests made with fly ash-lime, as often used for stabilization abroad, have shown too slow binding for a rather cold climate. Addition of waste gypsum, calcium chloride, alkali-salts or use of an alkali-rich cement kiln dust instead of commercial lime can improve the binding properties. Different fly ashes, however, react in different ways. It is often more suitable to use fly ash-cement as a binder, especially with poorly graded aggregates. The fly ash, added in an optimum amount, work as a filler and high immediate stabilities can be achieved at a correct water content. The puzzolanic properties of the fly ash, at the same time, makes it possible to reduce the cement content considerably in comparison with the case when only portland cement is used as a binder.
\end{abstract}

Promising laboratory work has also been done with binders consisting of condensed silica fume or ash from fluidized bed coal combustion, both in combination with lime.

\section{Résumé}

Les dépôts de sables naturels et les rebuts de criblage de ballastières et de carrières sont abondants en Suède. Des recherches ont été faites pour stabiliser de tels matériaux à l'aide de liants à base de déchets. On a réalisé à la fois des essais de laboratoire et des tests sur chaussées, principalement sur renforcements de routes secondaires avec des couches de base variées.

De bons résultats ont été obtenus avec un liant de laitier de hauts fourneaux granulé et broyé, activé par de la chaux ou à la fois par de la chaux et un déchet gypseux. Les sables et les produits de criblage des gravières contiennent souvent de la matière organique, poison des liants étudiés. Dans de tels cas, l'addition de gypse semble contrecarrer l'action négative de la matière organique.

Des cendres volantes sont utilisables depuis peu en Suède. Des essais réalisés avec des cendres volantes-chaux, équivalentes à celles souvent utilisées en stabilisation à l'étranger, ont montré un durcissement trop lent pour un climat plutôt froid. L'addition de déchet de gypse, de chlorure de calcium, de sels alcalins ou l'utilisation de poussières de four à ciment riches en alcalins au lieu de chaux commerciale permet d'améliorer les propriétés des liants. Différentes cendres volantes réagissent cependant de manières variées. Il vaut souvent mieux utiliser des cendres volantes-ciment comme liant, en particulier avec les matériau x à granularité défavorable. Les cendres volantes ajoutées en pourcentage optimal se comportent comme un filler et on peut ainsi obtenir une haute stabilité immédiate avec une teneur en eau correcte. Les propriétés pouzzolaniques de la cendre volante permettent, en même temps, de réduire considérablement le pourcentage de ciment par rapport au cas où on r'utiliserait que du ciment portland comme liant.

Un travail prometteur a aussi été fait en laboratoire sur des liants obtenus à partir de fumées de silice condensées ou de cendres de construction du charbon en lits fluidisés, dans tous les cas en combinaison avec la chaux.

\section{Introduction}

Sweden is favoured with extensive resources of natural aggregates of good quality, originating both from gravels from glaciofluvial deposits and crystalline bedrock. Regional shortages exist, however, and the extraction of gravel has been made more difficult by environmental protection measures. The ambition to save natural resources and energy has initiated research in using marginal aggregates and binders, based on waste materials, in road constructions.

* National Swedish Road and Traffic Research Institute (VTI) Fack, 58101 Linköping, Sweden.
At the VTI, laboratory work has been performed and test roads built, mainly on contracts with the Swedish Road Administration. In connection with test roads, stabilized road bases have mainly been studied, often when strengthening unsurfaced secondary roads. In such cases a cheap surfacing e.g. surface dressing made with graded gravel, can be used. However, it is considered important to have an especially strong base in such cases.

Besides unbound bases only bitumen, and cementbound bases are currently standardized in Sweden. Cement stabilized bases have, however, been used to a minor extent when building new roads because thick asphalt bound layers have been considered necessary to prevent reflective 
cracks appearing in the road surface. Such cracks do not necessarily degrade the bearing capacity of the pavement.

The climatic conditions also prevent the pavement from being made frostproof because of the great thicknesses necessary to prevent frost penetrating the subgrade. Rigid stabilizations, made with hydraulic or puzzolanic binders, are less suitable than flexible ones when the subgrade soils are frost-susceptible. Because of these problems, it is necessary to study construction methods, already used abroad, in more severe climatic conditions in order to define the applications.

The marginal aggregates stabilized have mainly been sand and fine grained screenings from crushing gravel or rock. The aggregates have sometimes been contaminated by organic material that complicates the use of the binders studied. These have been based on either activated granulated blast furnace slag or fly ash, mixed with lime or cement. Other waste products have also been studied in laboratory tests. Granulated blast furnace slag, activated with a small amount of lime, cement, $\mathrm{NaOH}$, gypsum etc. is, like portland cement, classified as a hydraulic binder. Fly ash, obtained from burning high rank coals, contains little lime and lime or cement must be added for a binding action. The binder is therefore classified as puzzolanic.

\section{Blast furnace slag as a binder}

At the beginning of the seventies an attempt was made in Sweden to use lime activated unground granulated blast furnace slag in stabilized road bases as first done in France [1]. Good results have often been obtained when watercooled blast furnace slag was used as an aggregate and a ready-mix was introduced by a steel industry. The attempts to stabilize natural aggregates were, however not so successful, partly because of the rather "acid" nature of the slags which leads to poor binding properties. The aggregates are also mostly of granitic composition and consequently less suitable than e.g. limestone or air-cooled blast furnace slag. Also the asphalt surfacings used were comparatively thin, $4 \mathrm{~cm}$ asphaltic concrete as maximum.

The binding properties of the granulated slag can be improved if the specific surface is increased by grinding. In France, preground slag with a fines $(<0.08 \mathrm{~mm})$ content of $10-15 \%$ has been introduced [2]. This binder can be stored for some time in a stockpile in the open air and is plant-mixed when an activating agent is added. In Sweden, however, the granulated slag has been ground to approximately cement fineness. This binder can be added in smaller amounts and can be bulktransported longer distances by truck. Existing equipment for handling cement can be used. The mixes have been made in a cement stabilization plant or in plant used for producing the oiled gravel surfacing used on secondary roads in Sweden. Also batch mixes in concrete plant have been made. Control of the binder content has, however, sometimes been inadequate. The ground slag has been activated with $10 \%$ lime, but it has later been learnt that the addition of waste gypsum can give considerably improved properties.

The first test road, Hissjö 1980, built with ground, lime activated slag, was made in late August near Umeâ in northern Sweden, in connection with strengthening of road 363 with a $15 \mathrm{~cm}$ thick stabilized base [3]. Oiled gravel was used as surfacing. The average daily traffic with a large number of heavy lumbertrucks. The subgrade was a welldrained sand.

The aggregate was varied, both a gravelly and a sandy grading being used (table 1 ). The binder content was conparatively high, about $10 \%$, but could not be contro! led as carrefully as desired. A test section was also lai without adding lime as activator. Also fly ash-lime $w_{\text {is }}$ studied as a binder, see chapter 3 .

Little time was available when laying the test sections and heavy rain caused problems. Oiled gravel was immideatel. laid on the compacted base and the road was opened in traffic. The mix made with gravelly material was observe: to be more sensitive to a high water content than the sandy one. The deformations caused by heavy traffic wera shaped with additional low binder content oiled gravel which became thicker than planned. The final surfacing $w_{a}$; laid later.

The developement of bearing capacity of the test sections was determined with the aid of a falling weight deflecto. meter. The deflection was measured at two points whic:. enabled calculation of the layer moduls of the stabilize: layers and modulus for the underlying unbound layers [4]. These values depend on enviromental conditions e.s. the moisture contents in the materials. Cores were als? extracted from the bound layers for determination of th: compressive strength. This test was made according to th: specification of the Swedish Road Administration, whic: means that rubber pads are used between the test spec: mens and steel plates of the loading machine. In this way a splitting type of failure is induced, which means that the strength value for a well-bound specimen with low slen. derness (height/diameter) is reduced, e.g. with abou: $50 \%$ for a laboratory compacted Proctor-sized specimen The influence of the slenderness is, however, minimal ar: the results seem to correspond to the compressive strength. obtained at a slenderness of 2.0 , as recommended $\mathrm{r}$ : PIARC [5].

In spite of the unfavourable weather conditions when layir: the test sections, good results have been obtained wit: the slag stabilized materials. The sandy material has perfo: med as well as the gravelly one. The slag binder seems:be less sensitive to a high water content than portlan: cement, a fact also observed when using slag cement :: concrete [6]. The section with non-activated slag, in spi:: of the slow binding, has with time achieved layer moduli. values of the same level as sections with the lime-activati: binders. The modulus values, however, show some decreax. especially according to measurements made in spr: : 1983, which is probably due to increased cracking, n: seen on the road surface. A good relationship between the compressive strengths of cores and layer modulus val... can be observed before any significant reduction of $t:$ : latter has occurred. Some transverse cracks have form: in the road surface, mostly in transitions between the t: sections.

The freeze-thaw durability of the material compositions : the test sections has been studied in the laboratory water saturation in vacuum of test cylinders and exposi: to 10 freeze-thaw cycles in a frost cabinet. The samp: which have been moist stored for 135 days have bet embedded in moist sand. The freeze-thaw durability. evaluated by the expansion and strength reduction of $\because:$ samples, is excellent for the well-bound materials. Se: healing properties are also found when fitting cracked cimens together with rubber bands and storing them ir. moist environment. The original strength can be obtain?: or even exceeded when storing specimens for a sufficien: long time. The importance of such autogenous healing $i:$. be disputed, in road conditions e.g. the transverse and lon:tudinal cracks formed mostly lack the stress condition: necessary for healing. Also this property probably decliris: with time. 
Tab. 1: Test road Hissjö 1980. Average values from falling weight deflectometer measurements (layer modulus of stabilized courses) and compressive strength of cores (values in brackets)

\begin{tabular}{|c|c|c|c|c|c|c|c|}
\hline \multirow{2}{*}{$\begin{array}{l}\text { Test } \\
\text { section }\end{array}$} & \multirow{2}{*}{$\begin{array}{c}\text { Aggregate } \\
\text { and binder } \\
\text { composi- } \\
\text { tion }\end{array}$} & \multicolumn{6}{|c|}{$\begin{array}{l}\text { Layer modulus, MPa } \\
\text { (compressive strength of cores, MPa) }\end{array}$} \\
\hline & & 800930 & 810520 & 810917 & 820605 & 820906 & 830614 \\
\hline 1 & $\begin{array}{l}\text { gravelly, } \\
10 \% \text { slag } \\
1 \% \text { lime }\end{array}$ & $\begin{array}{l}8800 \\
(6.0)\end{array}$ & $\begin{array}{l}20900 \\
(10.2)\end{array}$ & $\begin{array}{l}26200 \\
(14.2)\end{array}$ & $\begin{array}{l}29900 \\
(12.2)\end{array}$ & 24300 & $\begin{array}{l}14673 \\
(15.7)\end{array}$ \\
\hline 2 & $\begin{array}{l}\text { sandy, } \\
10 \% \text { slag } \\
1 \% \text { lime }\end{array}$ & $\begin{array}{c}10100 \\
(5.1)\end{array}$ & $\begin{array}{c}23300 \\
(9.4)\end{array}$ & $\begin{array}{l}32500 \\
(12.9)\end{array}$ & $\begin{array}{c}39500 \\
(8.8)\end{array}$ & 18500 & $\begin{array}{l}20494 \\
(13.4)\end{array}$ \\
\hline 3 & $\begin{array}{l}\text { sandy, } \\
13 \% \text { slag }\end{array}$ & 1200 & $\begin{array}{c}10300 \\
(4.9)\end{array}$ & $\begin{array}{c}13500 \\
(9.4)\end{array}$ & $\begin{array}{l}27200 \\
(10.3)\end{array}$ & 32100 & $\begin{array}{l}19914 \\
(11.4)\end{array}$ \\
\hline 4 & $\begin{array}{l}\text { sandy, } \\
16 \% \text { fly ash } \\
4 \% \text { lime }\end{array}$ & $\begin{array}{c}530 \\
-\end{array}$ & $\begin{array}{c}680 \\
-\end{array}$ & $\begin{array}{l}4300 \\
(3.0)\end{array}$ & $\begin{array}{l}4400 \\
(2.4)\end{array}$ & 8100 & $\begin{array}{l}6715 \\
(6.9)\end{array}$ \\
\hline 5 & $\begin{array}{l}\text { sandy, } \\
16 \% \text { fly ash } \\
4 \% \text { lime } \\
1 \% \mathrm{CaCl}_{2}\end{array}$ & $\begin{array}{c}1700 \\
-\end{array}$ & $\begin{array}{c}680 \\
(3.3)\end{array}$ & $\begin{array}{c}10600 \\
(5.7)\end{array}$ & $\begin{array}{c}14000 \\
(5.9)\end{array}$ & 11400 & $\begin{array}{l}6860 \\
(9.3)\end{array}$ \\
\hline 6 & $\begin{array}{l}\text { gravelly, } \\
12 \% \text { fly ash } \\
3 \% \text { lime } \\
1 \% \mathrm{CaCl}_{2}\end{array}$ & $\begin{array}{c}2300 \\
-\end{array}$ & $\begin{array}{c}4500 \\
-\end{array}$ & $\begin{array}{c}13200 \\
(7.9)\end{array}$ & $\begin{array}{c}16800 \\
(5.8)\end{array}$ & 11500 & $\begin{array}{l}9848 \\
(8.4)\end{array}$ \\
\hline 7 & $\begin{array}{l}\text { gravelly, } \\
12 \% \text { fly ash } \\
3 \% \text { lime }\end{array}$ & 800 & $\begin{array}{c}980 \\
-\end{array}$ & $\begin{array}{l}7300 \\
(6.1)\end{array}$ & $\begin{array}{c}20800 \\
(7.8)\end{array}$ & 26600 & $\begin{array}{l}16940 \\
(11.3)\end{array}$ \\
\hline
\end{tabular}

Tab. 2: Test road Sollebrunn 1981. Average values from falling weight deflectometer measurements (layer modulus of stabilized base) and compressive strength of cores (values in brackets)

\begin{tabular}{|l|c|c|c|c|c|c|c|c|}
\hline \multirow{2}{*}{ Binder } & \multicolumn{6}{|c|}{ Layer modulus, MPa (compressive strength of cores, MPa) } \\
\cline { 2 - 9 } & 8106 & 8107 & 8109 & 8203 & 8204 & 8209 & 8304 & 8310 \\
\hline $9 \%$ milled & 14400 & 20100 & 19500 & 15600 & 18800 & 18600 & 12200 & 16300 \\
slag & & $(7.9)$ & $(10.0)$ & - & $(9.3)$ & $(11.4)$ & - & $(14.7)$ \\
$\begin{array}{l}\text { 6\% port } \\
\text { land } \\
\text { cement }\end{array}$ & $\begin{array}{c}11500 \\
(3.8)\end{array}$ & $\begin{array}{c}13000 \\
-\end{array}$ & $\begin{array}{c}7800 \\
-\end{array}$ & $\begin{array}{c}2800 \\
-\end{array}$ & $\begin{array}{c}5900 \\
(4.0)\end{array}$ & $\begin{array}{c}2200 \\
(3.8)\end{array}$ & $\begin{array}{c}1100 \\
-\end{array}$ & $\begin{array}{c}1500 \\
(3.7)\end{array}$ \\
\hline
\end{tabular}

The next test with a slag binder was made in summer 1981 :t Sollebrunn in south-west Sweden [7] in connection with trengthening of a minor unsurfaced road with a $15 \mathrm{~cm}$ inck stabilized base. The subgrade soil was a clay. The sgregate used was screenings $0.8 \mathrm{~mm}$ originating from if processing of gravel. $9 \%$ lime-activated slag binder ias used. The compacted base was sealed with cutback sphalt and later provided with a surface dressing made "ith graded aggregate. Transverse cracks occurred a short me after construction and further cracks appeared the jlowing winter. Construction was performed during a ng warm summer period and drying out of the sealed aterial has probably occurred.

tracted cores show a strength gain during the 2 year ing observation period (table 2). However, no such strength in can be observed in the portland cement stabilized aterial, used for the rest of the road where the binder intent is lower, $6 \%$. The layer modulus (table 2) has ireased to a certain degree for the slag stabilized material

to a major extent for the cement stabilized one because degradation. The cracking of the road surface is also more severe for the cement stabilized than for the slag. stabilized sections. A similar degradation of a cement stabilized Swedish road has been described earlier [4].

In August 1980 a test road was constructed at Gärdhem, near Trollhättan, not far from the former one [8]. The same aggregate was used, the traffic and subgrade soils are similar, as are the stabilized base layer thickness and surfacing. This time, however, the binder composition was varied and also low binder contents, 4,6 and $8 \%$ limeactivated slag binder, were studied. Sections with added waste gypsum $(0.5,0.75$ and $1 \%$ respectively) were laid for comparison (table 3). Test sections with flyash-cement were also laid, see chapter 3 .

The construction of the test sections was performed in different weather conditions. The material, containing only $4 \%$ slag binder, became unstable because of heavy rain and was strengthened the next day with a $10 \mathrm{~cm}$ layer containing $8 \%$ slag binder. Material containing $4 \%$ binder, and also $0.5 \%$ gypsum, was laid in the same weather conditions but had gained some strength and was therefore 
Tab. 3 : Test road Gärdhem 1982. Average values from falling weight deflectometer measurements (layer modulus of stabilized base) and compressive strength of cores (values in brackets)

\begin{tabular}{|c|c|c|c|c|c|}
\hline \multirow{2}{*}{$\begin{array}{l}\text { Test } \\
\text { section }\end{array}$} & \multirow{2}{*}{$\begin{array}{l}\text { Binder } \\
\text { composition }\end{array}$} & \multicolumn{4}{|c|}{$\begin{array}{c}\text { Layer modulus, } \mathrm{MPa} \\
\text { (Compressive strength, MPa) }\end{array}$} \\
\hline & & 820902 & 820922 & 830414 & 831005 \\
\hline 1 & $\begin{array}{l}10.0 \% \text { fly } \\
\text { ash } \\
2.0 \% \text { cement }\end{array}$ & 2400 & $\begin{array}{l}3800 \\
(1.7)\end{array}$ & $\begin{array}{r}4000 \\
(3.9)\end{array}$ & $\begin{array}{l}7100 \\
(7.3)\end{array}$ \\
\hline 2 & $\begin{array}{l}6.0 \% \text { fly } \\
\text { ash } \\
3.0 \% \text { cement }\end{array}$ & 2300 & $\begin{array}{l}3300 \\
(1.6)\end{array}$ & $\begin{array}{l}3250 \\
(2.3)\end{array}$ & $\begin{array}{l}6400 \\
(5.7)\end{array}$ \\
\hline 3 & $\begin{array}{l}8.0 \% \text { slag } \\
4.0 \% \text { slag* }\end{array}$ & 700 & $\begin{array}{c}6000 \\
-\end{array}$ & $\begin{array}{c}72700 \\
(5.7)\end{array}$ & $\begin{array}{c}110000 \\
(6.8)\end{array}$ \\
\hline 4 & $\begin{array}{l}4.0 \% \text { slag } \\
0.5 \% \text { gypsum }\end{array}$ & 3500 & $\begin{array}{c}10900 \\
(2.5)\end{array}$ & $\begin{array}{l}9000 \\
(5.6)\end{array}$ & $\begin{array}{c}13300 \\
(5.9)\end{array}$ \\
\hline 5 & $6.0 \%$ slag & 2300 & $\begin{array}{c}11300 \\
(2.7)\end{array}$ & $\begin{array}{l}8200 \\
(5.2)\end{array}$ & $\begin{array}{l}8900 \\
(6.4)\end{array}$ \\
\hline 6 & $8.0 \%$ slag & 11800 & $\begin{array}{c}16400 \\
(4.5)\end{array}$ & $\begin{array}{c}15000 \\
(5.8)\end{array}$ & $\begin{array}{c}18100 \\
(8.5)\end{array}$ \\
\hline 7 & $\begin{array}{l}8.0 \% \text { slag } \\
1.0 \% \text { gypsum }\end{array}$ & 26000 & $\begin{array}{l}22900 \\
(11.5)\end{array}$ & $\begin{array}{l}17900 \\
(13.7)\end{array}$ & $\begin{array}{l}17400 \\
(16.6)\end{array}$ \\
\hline 8 & $\begin{array}{l}8.0 \% \text { fly } \\
\text { ash } \\
6.0 \% \text { slag }\end{array}$ & 9200 & $\begin{array}{c}15000 \\
(4.5)\end{array}$ & $\begin{array}{l}14300 \\
(10.2)\end{array}$ & $\begin{array}{l}15900 \\
(11.1)\end{array}$ \\
\hline 9 & $\begin{array}{l}6.0 \% \text { slag } \\
0.75 \% \text { gypsum }\end{array}$ & 10500 & $\begin{array}{c}16200 \\
(4.4)\end{array}$ & $\begin{array}{c}14300 \\
(9.0)\end{array}$ & $\begin{array}{l}14800 \\
(10.1)\end{array}$ \\
\hline $\begin{array}{l}\text { Refe- } \\
\text { rence }\end{array}$ & $\begin{array}{l}6.0 \% \text { portland } \\
\text { cement }\end{array}$ & - & - & - & $\begin{array}{l}5500 \\
(4.5)\end{array}$ \\
\hline
\end{tabular}

* Section with $4.0 \%$ slag strengthened with $10 \mathrm{~cm}$ material with $8 \%$ slag. Compressive strength determined on bottom layer.

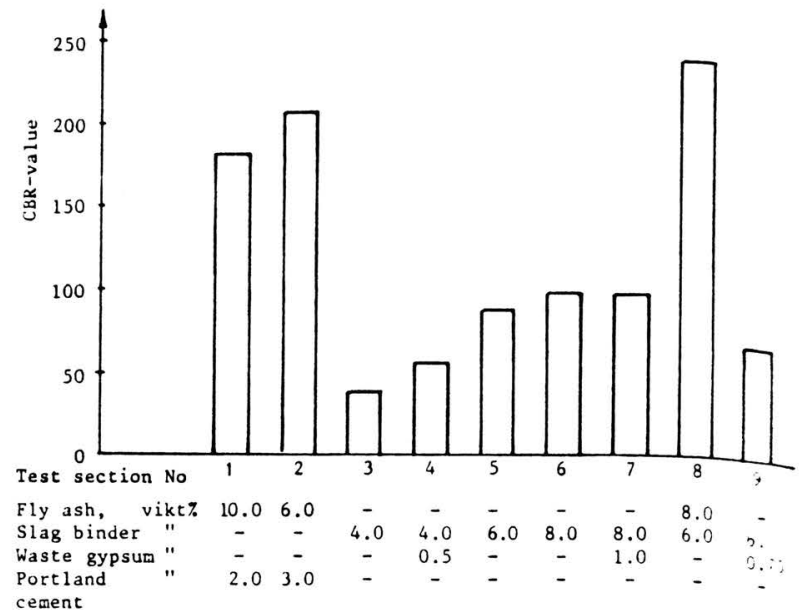

Fig. 1: Immediate stability for material compositions in test rout Gärdhem 1982. Water content $6.0 \%$.

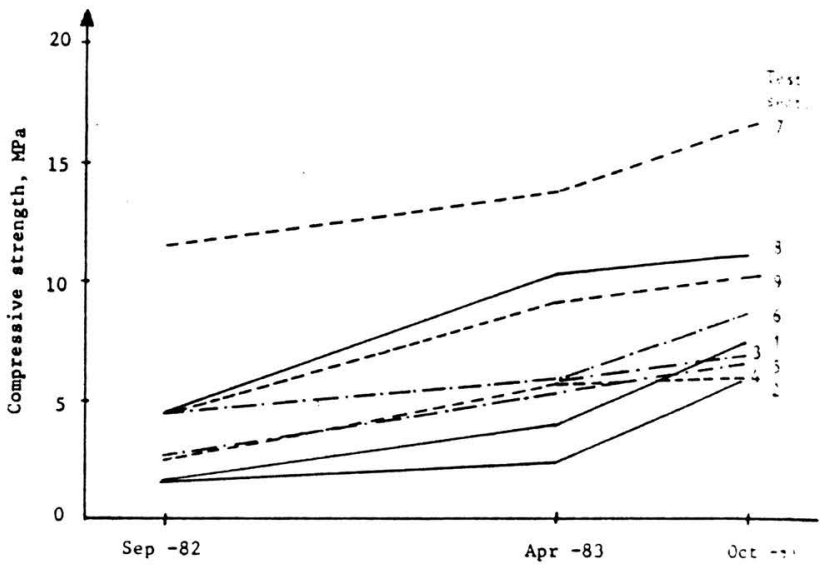

Fig. 2: Developement of compressive strength, determined on cores drilled from test road Gärdhem 1982.

\section{Fly ash-lime and fly ash-cement as binders}

not strengthened. CBR-tests, as performed in France, were made to control the immediate stability of the unbound materials (Fig. 1) and a good measure of agreement with the observations during laying of the test sections was achieved.

The falling weight deflectometer measurements show a continuous increase of the bearing capacity of the different text sections (table 3 ). Extracted cores show a strength gain, also for the material containing only $4 \%$ binder (Fig. 2 ). The addition of waste gypsum has benefited the binding properties still more than observed in laboratory tests.

No transverse cracks were observed in the test sections after construction, contrary to the test road at Sollebrunn. The main difference has been the weather conditions ; the test road at Gärdhem was constructed later in the summer during wet weather conditions and no excessive drying and shrinkage of the material has occured. It may be added, that in the Netherlands the importance of preventing moisture loss has been observed when applying cement stabilizations and the asphaltic surface is laid immediately after the stabilized base [9]. A few narrow transverse cracks were observed the following spring. However, more extensive cracking has occurred during the summer 1983, which has been extremely hot and dry. It cannot be excluded that the drying out of the clay subgrade under the pavement may have exerted an influence.
Coal has not been used as a fuel in Sweden for some decades because of the availability of low priced oil. Howeve? in recent years, some coal-fired plants have been built. mainly for heating, although new plants are also planned for electricity generation. In the USA, France $[10,11]$ uns some other countries, fly ash from high-ranked coals has been used in combination with lime for stabilization of pavements. Studies of this binder were taken up by the VTI in 1980. The laboratory tests showed that fly ash-lime compositions had very slow binding properties but the addition of a low content of waste gypsum, calcium chio ride, sodium silicate etc, could improve the binder. F:y ashes, however, react in a different way and testing must to performed in each case.

Test sections were laid with fly ash-lime stabilized base in the test road Hissjö 1980 [3]. The binder contents were $12-16 \%$ fly ash and $3-4 \%$ lime. Test sections were also laid with the addition of $1 \%$ calcium chloride (table !! The dry fly ash was fed from a cement silo which causic some handling difficultes. Rainy weather in combination with heavy vehicles caused deformations in the unbound material and were adjusted with oiled gravel.

No cores were obtained when a first drilling attempt wts made one month after construction. However, some bin- 
ding could be observed in the calcium chloride activated materials. Next spring, cores were obtained only from these sections but in the autumn also from the unactivated materials. The falling weight deflectometer measurements show a faster increase of layer modulus values for the activated material sections, but with time the gravelly aggregate mixes get the highest values. The calcium chloride activated materials seem to have cracked to some extent because it has become increasingly difficult to obtain winbroken cores. However, no decrease in compressive strength can be seen for the unbroken cores tested. Some transverse cracks have appeared the second winter in the road surface.

As the slag stabilized materials, also the fly ash-lime stabilized ones have had good freeze-thaw durability after binding and also show autogenous healing.

Because of the slow binding action of the fly ash-lime binder compositions fly ash-portland cement binder has also been studied. This binder is favourable especially with poorly graded aggregates, e.g. sand. Good results were obtained in the laboratory with high fly ash and low cement content binders and two short test sections were constructed in the test road Gärdhem 1982 [8]. Moist, stockpiled fly ash was used this time in compositions with $10 \%$ ash, $2 \%$ cement and $6 \%$ ash, $3 \%$ cement (table 3 ). An unplanned test section was also laid with $8 \%$ fly ash and $6 \%$ slag binder, since these components were in excess. The fly ash, stored in a small stockpile, became quite wet in rainy weather and some difficulties arose in the mixing process. The fly ash tended to form rounded agglomerates a few $\mathrm{cm}$ in size that were also present after compaction. The stabilities of the unbound materials were however high and they resisted truck traffic well. Also the corresponding CBR-values in the laboratory were high, figure 1.

The short-term strengths according to cores were considerably poorer than that obtained in former laboratory tests, mainly because of the poor mixing (table 3 ). However, the compressive strengths improve with time (figure 2). The falling weight deflectometer measurements show the same tendency. It can also be observed that the test sections, containing fly ash-cement, have lower layer modulus values than the slag stabilized sections at the same level of compressive strength. It is assumed that the resilient characteristics of porous fly ash can exert an influence. The fly ash-slag treated section performed favourably and the slag content (the most expensive component) could have been lower.

According to freeze-thaw testing, the durability of the material, bound with $10 \%$ fly ash and $2 \%$ cement, is unsufficient after 3 months hardening. However, no signs of degradation were observed during the first winter.

because of the considerable interest in fly ash utilization, c test road was built in summer 1983 in the town of Västeas. This time a new road was built, with a traffic volume of 12000 vehicles/day. The aggregates studied used in in stabilized base were a $0-32 \mathrm{~mm}$ gravel and $0-8 \mathrm{~mm}$ ireenings respecticely. The fly ash content was $6 \%$ in the ormer and $10 \%$ in the latter case because of the poorer tading. Dry silo ash was used. Cement contents of $2 \%$ and $3 \%$ were studied with both aggregates. Shorter test xictions were also laid with cement-stabilized fly ash $10 \%$ binder) as a base material and unstabilized fly ash moist ash from stockpile) as a subbase material. The surdining consisted of a $4 \mathrm{~cm}$ thick asphaltic concrete. The shgrade soil was a soft clay.

he road base materials were batch-mixed in a concrete ant. The sandy material was more easily handled than the gravelly one because the latter was well graded and dense, and therefore sensitive to moisture content. Also it tended to segregate. The strength gain is fairly similar but the layer modulus values tend to be lower for test sections with the sandy material. The compressive strengths and layer modulus values, monitored the first year are considerably higher than from the test road Gärdhem 1982 for similar binder cimpositions and obviously the dry silo ash has worked better than the wet stockpiled fly ash. Both came from the same plant.

Narrow transverse cracks in the sealed surface occurred some days after construction, especially when the weather was sunny, and some have later penetrated the asphaltic concrete.

\section{Stabilization with other waste materials}

Laboratory tests have been made with other puzzolanic binders, e.g. condensed silica fume (of impure quality, unsuitable for concrete) ash from fluidized bed combustion of coal etc. These have been tested both with commercial lime and with waste lime. The results have often been better than with fly ash. Condensed silica fume especially is a good puzzolan and can be used in a lower content than fly ash. Also alkali-rich waste lime from a cement kiln has given excellent results, better than commercial lime.

\section{Aggregates containing organic material}

Marginal materials such as glacial tills and sands may be contaminated by organic material that retards or hinders the binding action of both hydraulic and puzzolanic binders. Standardized tests for aggregate quality are sometimes misleading, e.g. the commonly employed colorimetric test in $\mathrm{NaOH}$-solution. Also the $\mathrm{pH}$-values, both of the aggregate and hydrating mixtures have been measured, but the results are not always in agreement with the strength development of the materials. The strength gain of aggregatebinder combinations must therefore be evaluated in suspicious cases with different binders and additives.

There are various measures for counteracting the negative influence of organic contamination. Slag binder is particularily sensitive but can be improved by gypsum or alkaline salts. Road 626 near Kungälv for example was strengthened in 1981 with a base, made of screenings from a gravel pit, stabilized with lime-activated slag binder. According to laboratory tests, the strength development was very slow but the addition of waste gypsum or potassium sulphate improved the properties. For practical reasons, the latter was used in $0.3 \%$ content when strengthening the road.

Laboratory tests were also made in 1983 in connection with strengthening of road 1175, not far from Vingaker. A natural sand, containing an active organic contaminant, was used as an aggregate. Various binders were studied in different contents in order to find the most suitable one [12]. Portland cement, slag-cement ( $70 \%$ slag content) and a modified cement (delivered with $30 \%$ fly ash) were studied and in addition also lime activated slag, fly ash-cement, fly ash-lime and silica-lime binders. Additions of different chemicals in low contents were also studied.

With portland cement, quite unsatisfactory results were achieved and no strength gain was observed after 7 days. Additions of calcium chloride, gypsum and alkaline salts gave no significant improvements. Better results were achieved with slag-cement and fly ash containing cements. The 
short term strengths were low, but contrary to portland cement, a strength gain was observed. Lime-activated slag binder did not work until waste gypsum or calcium chloride was added ; the short term strengths were low but significant strength gains were observed. The same thing can be said about fly ash-cement binder (moist fly ash was mixed with portland cement). Fly ash-lime did not work well, even with additives, but silica-lime was an efficient binder, especially in combination with alkali-rich waste lime.

The modified cement was used in a content of $7 \%$ when strengthening the road. A test section was also made when besides $4 \%$ cement also $10 \%$ moist, stockpiled fly ash was added. The stability of the material in the unbound state was greatly improved. According to compressive strengthtesting of on cores, taken one month after construction, the strengths of the both material compositions are equal. The layer modulus is, however, lower on the base, which is rich in fly ash.

\section{Conclusions}

Sandy materials have been successfully stabilized with different binders. The construction properties may under circumstances be better than with well-graded aggregates, because of a lower moisture sensitivity and lesser segregation when laying the material. However, adverse wet weather conditions must be avoided. The layer modulus values tend to be lower with sandy than gravelly aggregates.

Ground, lime activated, slag binder has given especially good results when waste gypsum has also been added. Also treament of aggregates, contaminated by organic substances, seems to be possible with a binder of this type.

Fly ash-lime binder has shown unacceptably slow binding properties, but improvement is possible by adding e.g. waste gypsum or calcium chloride. Fly ash-cement is a more useful binder in Swedish conditions, the short-term strength is sufficient and the strength increases during a long period. An important beneficial effect of the fly ash addition is also that poorly graded sands show greatly improved immediate stability and can, when protected from wetting up, withstand traffic stresses even in an unbound state. The freeze-thaw durability may be low for a binder with high fly ash content, but low in cement or lime content, until sufficient strength is gained.

Good results have also been achieved with non-traditional binders consisting of condensed silica fume-lime, fluidized bed coal combustion ash-lime etc. Alkali-rich waste lime can give better results than commercial lime.
Sometimes a decrease of the layer modulus values of t... sections have occurred, obviously because of cracking the materials which is not always seen in the road surface The compressive strength of cores may, however, be high The stabilized material condition is best monitored bearing strength measurements e.g. with a falling weigt deflectometer. Mainly transverse reflective cracks $h$. appeared after various times in the road surface and obvic: sly because of different reasons.

\section{References}

[1] Directive pour la réalisation des assises de chaussées en gra: laitier et sable-laitier. Ministère de l'Aménagement du $\mathrm{T}$ toire de l'Equipement du Logement et du tourisme $11, ;$

[2] Utilisation du laitier granulé prébroyé et bouleté prénro. pour le traitement des graves et des sables. Ministère Transports. Note Technique 1980.

[3] HÖBEDA P., JACOBSON T., VIMAN L. : The test R. Hissjö 1980. Construction (in Swedish). Statens Vig. Trafikinstitut, Meddelande 286, 1982.

[4] ÖRBOM B. : Field studies of long time structural performin. of two-layer pavement constructions. Bearing Capacity Roads and Airfields. Proc. Int. Symp. Trondheim, li.:

[5] PIARC : Technical Committee Report on testing of :...: materials, XII World Road Congress, Sydney 1983.

[6] MEUSEL J.W., ROSE J.H. : Production of granulated "1:? furnace slag at Sparrow Point, and the workability :strength potential of concrete incorporating the slag. Pr. 1 st Int. Conf. The use of fly ash, silica fume, slag and o: mineral by-products in concrete. Montebello 1983. ' 11: Publ. SP-79)

[7] JACOBSON T., VIMAN L. : The test road Sollebrunn 1, Construction (in Swedish) Statens Väg-och Trarikis:: : Meddelande 305, 1982.

[8] JACOBSON T., HÖBEDA P. : The test road Gärdhem 1. Construction (in Swedish). Statens Väg- och Trafikunst.at Meddelande 371 .

[9] JONKER C. : Sub-grade improvement and soil cement. In:at national Symposium on Concrete Roads, London 1982.

[10] National Cooperative Highway Research Program. Lime i' ash- stabilized bases and sub-bases. Synthesis of $\|: 2: \cdots$ Practice 37, 1976.

[11] Ministère des Transports : Recommandation pour la ridi:s:des assises de chaussées en graves-cendres volantes-itisis a sables-cendres volantes-chaux. Recommandation. 1978.

[12] HÖBEDA P., JACOBSON T., VIMAN L. : Stabilization * sand, contaminated by humus, with hydraulic and puzzes binders (in Swedish). Statens Vag- och Trafikinstitut V.2. lande $377,1983$. 


\section{d}

- Väg-och transport-

forskningsinstitutet

Forskar för ett liv i rörelse.

Statens väg- och transportforskningsinstitut har kompetens och laboratorier för kvalificerade forskningsuppdrag inom transporter och samhällsekonomi, trafiksäkerhet, fordon, miljö samt för byggande, drift och underhåll av vägar och järnvägar. 